\title{
New Scenarios of Chagas Disease Transmission in Northern Colombia
}

\author{
Catalina Tovar Acero, ${ }^{1}$ Jorge Negrete Peñata, ${ }^{2}$ Camila González, ${ }^{3}$ \\ Cielo León, ${ }^{3}$ Mario Ortiz, ${ }^{3}$ Julio Chacón Pacheco, ${ }^{4,5}$ Elkin Monterrosa, ${ }^{6}$ \\ Abraham Luna, ${ }^{7}$ Dina Ricardo Caldera, ${ }^{1}$ and Lyda Espitia-Pérez ${ }^{8}$ \\ ${ }^{1}$ Grupo de Investigación en Enfermedades Tropicales y Resistencia Bacteriana, Facultad de Ciencias de la Salud, Universidad del Sinú, \\ Montería, Colombia \\ ${ }^{2}$ Laboratorio de Investigaciones Biomédicas, Universidad del Sinú, Montería, Colombia \\ ${ }^{3}$ Departamento de Ciencias Biológicas, Centro de Investigaciones en Microbiología y Parasitología Tropical (CIMPAT), \\ Universidad de los Andes, Bogotá, Colombia \\ ${ }^{4}$ Fundación Colombia Mia, Montería, Colombia \\ ${ }^{5}$ Grupo de Investigación Biodiversidad Unicordoba, Universidad de Córdoba, Montería, Colombia \\ ${ }^{6}$ Área de Entomología, Laboratorio de Salud Pública de Córdoba, Montería, Colombia \\ ${ }^{7}$ Hospital San Juan de Sahagún, Sahagún, Colombia \\ ${ }^{8}$ Grupo de Investigación Biomédica y Biología Molecular, Facultad de Ciencias de la Salud, Universidad del Sinú, Montería, Colombia
}

Correspondence should be addressed to Catalina Tovar Acero; catalina@unisinu.edu.co

Received 30 May 2017; Revised 12 August 2017; Accepted 20 August 2017; Published 26 September 2017

Academic Editor: Bernard Marchand

Copyright (C) 2017 Catalina Tovar Acero et al. This is an open access article distributed under the Creative Commons Attribution License, which permits unrestricted use, distribution, and reproduction in any medium, provided the original work is properly cited.

Chagas disease (CD) is a systemic parasitic infection caused by the flagellated form of Trypanosoma cruzi. Córdoba department, located in the Colombian Caribbean Coast, was not considered as a region at risk of T. cruzi transmission. In this article, we describe the first acute CD case in Salitral village in Sahagún, Córdoba, confirmed by microscopy and serological tests. Our results draw attention to a new scenario of transmission of acute CD in nonendemic areas of Colombia and highlight the need to include CD in the differential diagnosis of febrile syndromes in this region.

Chagas disease (CD) also known as American Trypanosomiasis is a systemic parasitic infection caused by the protozoan parasite Trypanosoma cruzi (T. cruzi), which affects six to seven million people worldwide with an annual incidence of 28.000 cases in the Americas [1]. Transmission to humans as well as to domestic and sylvatic mammals occurs mainly through the introduction of the parasite present in triatomine bug feces during its blood meals; however, alternate transmission routes include blood transfusion, organ transplants, laboratory accidents, congenital and oral ingestion of contaminated food $[2,3]$. During the acute phase of the disease up to $30 \%$ of patients suffer from cardiac disorders and up to $10 \%$ suffer from digestive (typical enlargement of the esophagus, spleen, or colon), neurological, or mixed alterations [4].
Colombia has been one of the Latin American countries with a considerable number of acute Chagas disease outbreaks where oral transmission of $T$. cruzi has been recorded specially in endemic areas of Santander, Norte de Santander, Cundinamarca, Boyacá, Casanare, Meta, Arauca, and some areas of the Sierra Nevada of Santa Marta [5]. Córdoba department located in the Colombian Caribbean Coast is not considered as an endemic region for T. cruzi transmission; therefore $\mathrm{CD}$ is not included in the diagnosis of febrile diseases in hospitals and health centres. Additionally, due to the lack of knowledge about CD clinical symptoms, diagnosis in a setting where multiple infectious tropical diseases are present, such as tuberculosis, malaria, dengue, chikungunya, and Zika, is a challenge; therefore annual reports considered 


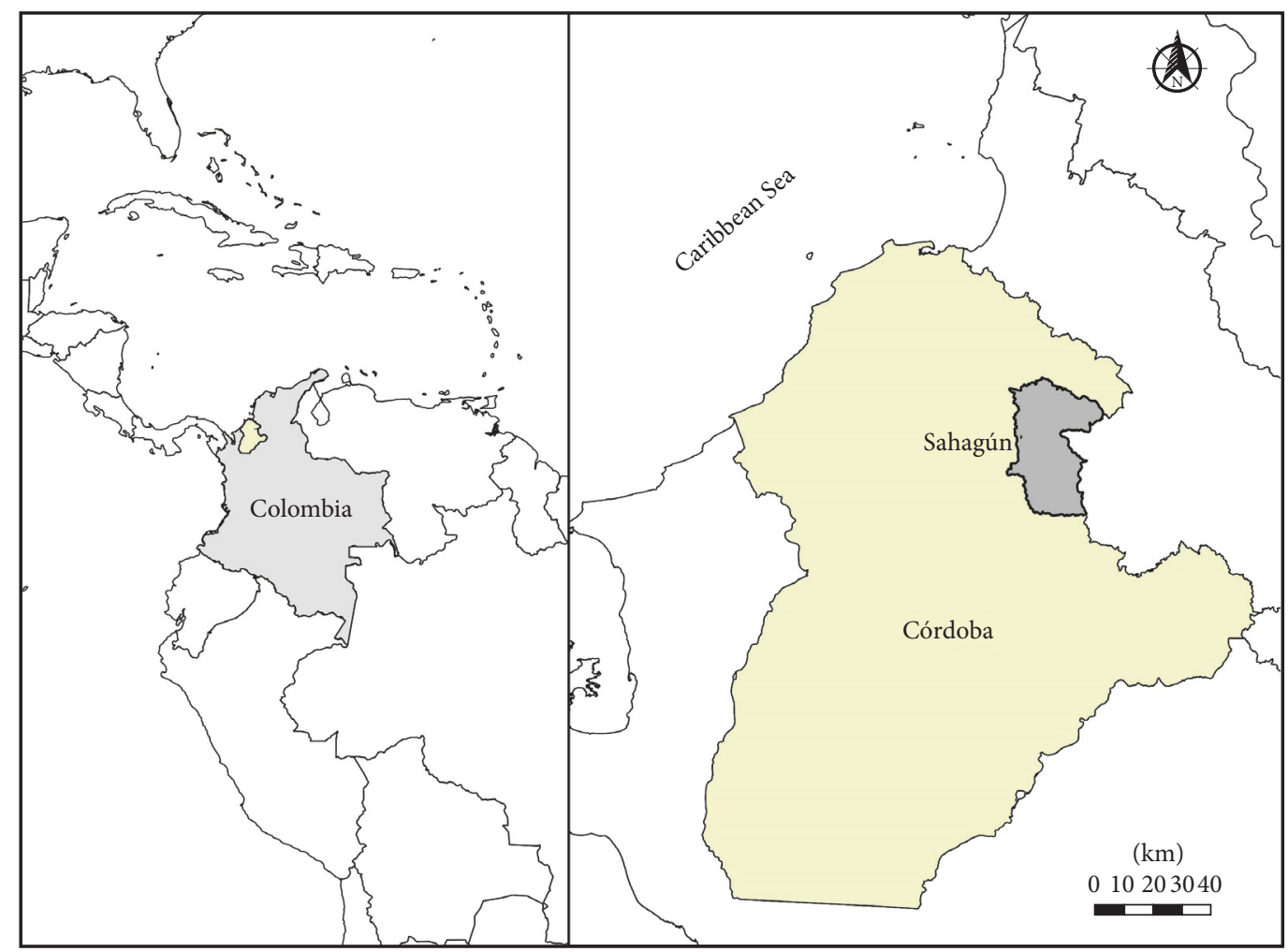

Figure 1: Sampling area (Salitral village, Córdoba, Colombia).

$\mathrm{CD}$ cases to be imported from other departments. In this article, we describe the first acute CD case in Salitral village in Sahagún, Córdoba, confirmed by microscopy and serological tests. Sampling area was located in Salitral village in the Sahagún municipality of Córdoba department, located in the northwest part of Colombia $\left(8^{\circ} 49^{\prime} 47.9^{\prime \prime} \mathrm{N}, 75^{\circ} 31^{\prime} 31.5^{\prime \prime} \mathrm{W}\right.$, and 75 m.a.s.l.) (Figure 1). This area has a tropical climate with an annual mean temperature between $27^{\circ} \mathrm{C}$ and $30^{\circ} \mathrm{C}$ and a relative humidity of $84 \%$. Main economic activities are related to mixed extensive crop-livestock systems, usually linked to the proliferation of wild small mammals (rodents and marsupials) described as T. cruzi reservoirs.

The 16-year-old young male patient born and resident in Salitral village was referred to the emergency service of San Juan de Sahagún Hospital (ESE HSJS) with eight days of headache and high fever $\left(38^{\circ} \mathrm{C}\right)$ associated with chills, generalized myalgia, asthenia, adynamia, choluria, severe epigastralgia without epistaxis, and gingivorrhagia. On his epidemiological history, the patient denied knowing triatomine bugs, having received any blood transfusion or organ transplant, or traveling outside Córdoba prior to the beginning of the symptoms. No inoculation point either in skin or periocular region suggesting vectorial transmission could be detected. The patient was alert, without respiratory distress or cardiovascular involvement (electrocardiogram). Abdominal palpation and ultrasound examination confirmed symptoms of a moderate spleen enlargement (splenomegaly). Thick blood smear examination was negative for Plasmodium spp. but positive for T. cruzi trypomastigotes (Figure 2).
Serological analysis by enzyme linked immunosorbent assay (ELISA) for CD was negative at the seventh day of hospitalization.

All experimental and sampling protocols were approved by the Ethics Committee of Universidad del Sinú according to national normativity for human populations studies and the NIH Guide for the Care and Use of Animals [6].

In order to determine the presence of triatomine bugs, active manual search was carried out by the professional staff and community members in walls, cracks in the walls and ceiling, mattresses, and floor of the patient's house and other 24 houses in the neighborhood area according to OMS recommended methodology [7]. Additionally, livebaited traps [8] and Gómez-Nuñez boxes [9] were also placed in the intra and peridomicile of each selected household. Taxonomic identification of captured specimens was performed based on external morphology, according to Lent and Wygodzinsky [10]. Detection of T. cruzi infection in captured triatomines was confirmed by direct and molecular techniques examining intestinal contents and rectal ampulla. Small- and mid-sized mammals were also captured using 5 mist nets for bats and 20 Tomahawks and 40 Sherman traps. Captured mammals were taxonomically identified according to Emmons and Feer [11], Linares [12], Tirira [13], Gardner [14], and Patton et al. [15] and whole blood samples were taken for molecular identification of T. cruzi. Sampling was performed on 80 volunteers selected from the entire population. All participants filled out a clinicalepidemiological survey including identification variables and 


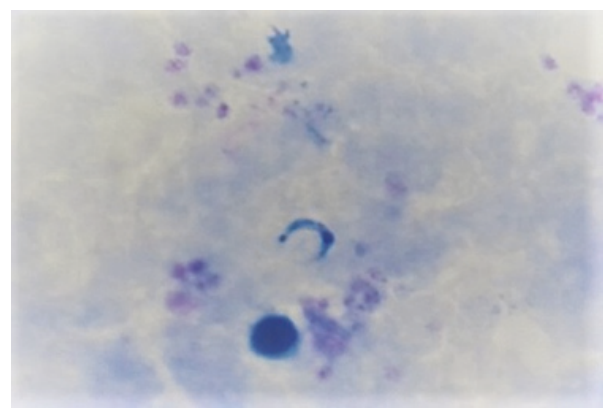

FIgURE 2: T. cruzi trypomastigotes detected in thick blood smears of the infected patient (1000x).

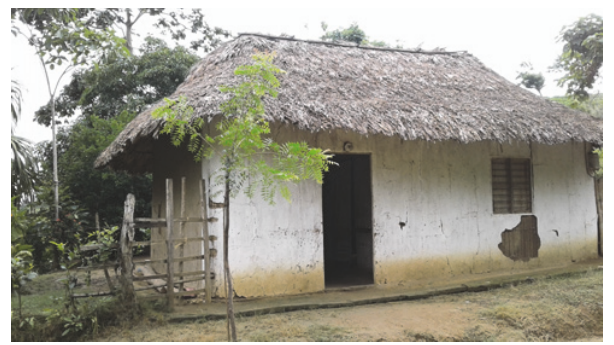

FIGURE 3: Patient's house infrastructure and peridomicile.

evidence of signs or symptoms according to case definition. All family members and other individuals related to the acute case patient were also analyzed. All samples were collected after obtaining the corresponding informed consent. The serological analysis included detection of IgG antibodies by ELISA and indirect immunofluorescence (IFI). For $T$. cruzi detection, human blood samples and triatomine bugs rectal ampulla were collected in a volume solution containing EDTA and guanidine $6 \mathrm{M}$ and stored at room temperature. A spin column-based nucleic acid purification kit was used to perform DNA extraction (High Pure PCR Template Preparation, de Roche $^{\circledR}$ ). Molecular detection was carried out through amplification of the variable region of kinetoplast DNA (kDNA) according to the methodology previously described by $[16,17]$ and tandem repeat satellite region from T. cruzi using the cruzil and cruzi2 primers described by [18]. Amplification cycles for $\mathrm{kDNA}$ were performed using a two-step procedure using an initial denaturation step at $94^{\circ} \mathrm{C}$ for $3 \mathrm{~min} ; 5$ cycles of denaturation at $94^{\circ} \mathrm{C}$ for $1 \mathrm{~min}$, annealing at $68^{\circ} \mathrm{C}$ for $1 \mathrm{~min}$, and extension at $72^{\circ} \mathrm{C}$ for $1 \mathrm{~min}$, followed by 35 cycles at $94^{\circ} \mathrm{C}$ for $45 \mathrm{sec}$; annealing at $64^{\circ} \mathrm{C}$ for $45 \mathrm{sec}$, extension at $72^{\circ} \mathrm{C}$ for $45 \mathrm{sec}$, and final extension at $72^{\circ} \mathrm{C}$ for $10 \mathrm{~min}$. Cycling conditions for cruzil and cruzi2 were initial denaturation at $94^{\circ} \mathrm{C}$ for $5 \mathrm{~min}$ and 40 cycles of denaturation at $94^{\circ} \mathrm{C}$ for $1 \mathrm{~min}$, annealing at $64^{\circ} \mathrm{C}$ for $30 \mathrm{sec}$, extension at $72^{\circ} \mathrm{C}$ for $1 \mathrm{~min}$, and final extension at $72^{\circ} \mathrm{C}$ for $10 \mathrm{~min}$. Patient's house was built with wood walls, palm roofs, and dirt floors surrounded by dense vegetation consisting of trees and palms (Figure 3). Among the 24 houses included in the study $32 \%$ were constructed with wooden walls, $40 \%$ with dirt floors, and 56\% with thatch palm roof and 32\% had unplastered walls. Conventional parasitological methods, serological screening, and molecular testing for detection of T. cruzi infection performed on blood samples of 80 voluntary patients showed negative results. In this particular community, serological test showed positive results only for the acute case described in this work. During the entomological sampling, seven individuals identified as Rhodnius pallescens and two classified as Panstrongylus geniculatus were captured. Most captured insects were collected by members of the community. Analysis of intestinal content and rectal ampulla confirmed the presence of T. cruzi in one specimen of each species. Analysis of blood samples of 29 specimens of small- and mid-sized mammals using molecular methods confirmed the presence of T. cruzi DNA in two specimens of Didelphis marsupialis and two specimens of Heteromys anomalus. The transmission scenario of CD in Córdoba still remains a challenge and must be addressed through clinical and ecoepidemiological studies since, as our results showed, a sylvatic cycle exists and accidental human cases might be occurring. In this particular case, signs and symptoms presented by the patient including prolonged febrile illness, epigastralgia, and absence of lesions in either the skin or the periocular region indicating the insect bite, together with patient statement of never being bitten by triatomines and never leaving Córdoba department, would suggest oral transmission as the most likely pathway of infection $[19,20]$.

Considering the T. cruzi detection in specimens of the triatomine bugs Panstrongylus geniculatus and Rhodnius pallescens and the mammals Didelphis marsupialis and Heteromys anomalus, there is an evident risk of infection to humans either. In Córdoba department previous studies reported the presence of several triatomine species [21]. In line with our findings, E. cuspidatus, P. geniculatus, and $R$. 
pallescens had previously been reported in Sahagún municipality [22]. However, no evidence of domiciliated triatomines was found. Even when no evidence of domiciliated P. geniculatus has been reported for Colombia, recent reports about the increasing frequency of Panstrongylus species displaying ability to invade and colonize human habitats are focusing the interest of entomologists and $\mathrm{CD}$ control managers throughout Latin America [23]. Current land use changes in Colombia and particularly in Córdoba, where vast forested areas have been cleared for livestock and agricultural activities, may favor triatomine domiciliation. This new situation could impose necessary changes in the strategy of CD control programs in Colombia, which until now have been limited to vector control activities in rural communities in endemic areas. Community engagement in sampling activities constituted a very effective approach for triatomine collection [24]. In our case, triatomine collection by community members was 3.5 times more effective compared to conventional sampling. These data are of key importance for the successful implementation of vector control in Córdoba and community participation could be a method of choice for sustained monitoring of triatomines in this area. Considering that there were no previous reports of T. cruzi infected reservoirs in Córdoba, our study represents the first report of T. cruzi infection detected in small mammals (Didelphis marsupialis and Heteromys anomalus) from this particular region. As documented by Cantillo-Barraza et al. [25], D. marsupialis may play an active role in the amplification of T. cruzi transmission in peridomestic areas mediating enzootic cycle or acting as a link between the enzootic and domestic cycles. In previous studies, Heteromys anomalus has been associated with sylvatic transmission cycles of CD in Colombia [26]. Our study also confirmed T. cruzi transmission in Salitral municipality evidenced by the presence of the parasite in different actors involved in the transmission cycle (human, reservoir, and vector). Even when no domiciliated vectors were found, our findings suggest the existence of autochthonous human cases in Córdoba and highlight the need to include CD in the differential diagnosis of febrile syndromes and diseases of this region. Despite the improvements in building materials and construction conditions of human dwellings in Córdoba, in some rural areas contact with natural and sylvatic environments persists, thereby creating the constant presence of potential vectors and reservoirs like triatomines, marsupials, and small mammals around the peridomicile. This close contact presumably could enable the emergence of $C D$ cases [27]. Similarly, in rural areas some practices related to food preparation and storage may also constitute a potential risk factor increasing the contact with triatomine feces and small mammals dejections [28]. This study draws attention to new scenarios transmission of $\mathrm{CD}$ in nonendemic areas of Córdoba department in Colombia and highlights the need to include $\mathrm{CD}$ in the differential diagnosis of febrile syndromes and diseases of this region.

\section{Conflicts of Interest}

The authors declare that there are no conflicts of interest regarding the publication of this article.

\section{Acknowledgments}

The authors gratefully wish to acknowledge the support of all the members of the Biomedical and Molecular Biology Laboratory of Universidad del Sinú for logistic cooperation during the sampling period. This research was supported by Gobernación de Córdoba and Sistema General de Regalías (SGR), Colombia (Grant no. 754/2013), and Universidad del Sinú-Elías Bechara Zainúm (UNISINU), Colombia.

\section{References}

[1] J. R. Coura and P. A. Vĩas, "Chagas disease: a new worldwide challenge," Nature, vol. 465, no. 7301, pp. S6-S7, 2010.

[2] K. Rueda, J. E. Trujillo, J. C. Carranza, and G. A. Vallejo, “Transmisión oral de Trypanosoma cruzi: un nuevo escenario epidemiológico de la enfermedad de Chagas en Colombia y otros países suramericanos," Biomédica, vol. 34, no. 4, 2014.

[3] J. F. Ríos, M. Arboleda, A. N. Montoya, E. P. Alarcón, and G. J. Parra-Henao, "Probable brote de transmisión oral de enfermedad de Chagas en Turbo, Antioquia," Biomédica, vol. 31, no. 2, p. 185, 2011.

[4] W.H.O., Chagas disease (American trypanosomiasis): Fact sheet $\mathrm{N}^{\circ} 340.2014$.

[5] Ministerio de la Protección Social, I.N.d.S., Organización Panamericana de la Salud OPS/OMS, Guía para la Atención Clínica Integral del paciente con enfermedad de Chagas. 2010: p. 1-81.

[6] Care, I.o.L.A.R.C.o., U.o.L. Animals, and N.I.o.H.D.o.R. Resources, Guide for the care and use of laboratory animals. 1985: National Academies.

[7] M. D. Feliciangeli, M. Hernández, B. Suarez et al., "Comparación de métodos de captura intradoméstica de triatominos vectores de la enfermedad de Chagas en Venezuela," Boletín de Malariología y Salud Ambiental, vol. 47, pp. 103-117, 2007.

[8] V. M. Angulo and L. Esteban, "Nueva trampa para la captura de triatominos en hábitats silvestres y peridomésticos," Biomédica, vol. 31, no. 2, p. 264, 2011.

[9] A. Longa and J. V. Scorza, "Acrocomia aculeata (Palmae), hábitat silvestre de Rhodnius robustus en el Estado Trujillo, Venezuela," Boletín de Malariología y Salud Ambiental, vol. 47, no. 1-2, pp. 213-220, 2007.

[10] H. Lent and P. Wygodzinsky, "Revision of the Triatominae (Hemiptera, Reduviidae), and their significance as vectors of Chagas disease," Bulletin of the American Museum of Natural History, vol. 163, pp. 123-520, 1979.

[11] L. Emmons and F. Feer, Neotropical Rainforest Mammals: A Field Guide, University of Chicago Press, 1997.

[12] O. J. Linares, Mamíferos de Venezuela, Sociedad Conservacionista Audubon de Venezuela, 1998.

[13] D. Tirira, "Guía de campo de los Mamíferos del Ecuador. Ediciones ed. 2007, Quito, Ecuador: Publicación especial sobre los mamíferos del Ecuador 6. 576-576".

[14] A. L. Gardner, Mammals of South America, Volume 1: Marsupials, Xenarthrans, Shrews, and Bats, University of Chicago Press, 2008.

[15] J. L. Patton, U. F. Pardiñas, and G. D’Elía, Mammals of South America, Volume 2: Rodents, University of Chicago Press, 2015.

[16] J. M. Burgos, J. Altcheh, M. Bisio et al., "Direct molecular profiling of minicircle signatures and lineages of Trypanosoma cruzi 
bloodstream populations causing congenital Chagas disease," International Journal for Parasitology, vol. 37, no. 12, pp. 13191327, 2007.

[17] A. G. Schijman, M. Bisio, L. Orellana et al., "International study to evaluate PCR methods for detection of Trypanosoma cruzi DNA in blood samples from Chagas disease patients," PLoS neglected tropical diseases, vol. 5, no. 1, e931 pages, 2011.

[18] M. Bisio, C. Cura, T. Duffy et al., "Trypanosoma cruzi discrete typing units in Chagas disease patients with HIV co-infection," Revista Biomédica, vol. 20, pp. 166-178, 2009.

[19] B. Alarcón de Noya, J. Veas, R. Ruiz-Guevara et al., "Evaluación clínica y de laboratorio de pacientes hospitalizados durante el primer brote urbano de enfermedad de chagas de transmisión oral en venezuela," Revista de Patologia Tropical, vol. 42, no. 2, 2013.

[20] L. Zuleta, "Enfermedad de Chagas: posible transmisión oral en trabajadores del sector hidrocarburos, Casanare, Colombia," Biomédica Revista del Instituto Nacional de Salud, vol. 37, no. 2, pp. 2-12, 2014.

[21] F. Guhl, G. Aguilera, N. Pinto, and D. Vergara, "Updated geographical distribution and ecoepidemiology of the triatomine fauna (Reduviidae: Triatominae) in Colombia," Biomedica, vol. 27, 2007.

[22] F. Guhl, G. Aguilera, N. Pinto, and D. Vergara, “Actualización de la distribución geográfica y ecoepidemiología de la fauna de triatominos (Reduviidae: Triatominae) en Colombia," Biomedica, vol. 27, no. 1, pp. 143-162, 2007.

[23] M. Reyes-Lugo and A. Rodriguez-Acosta, "Domiciliation of the sylvatic Chagas disease vector Panstrongylus geniculatus Latreille, 1811 (Triatominae: Reduviidae) in Venezuela," Transactions of the Royal Society of Tropical Medicine and Hygiene, vol. 94 , no. 5, p. 508, 2000.

[24] E. Dumonteil, M. J. Ramirez-Sierra, J. Ferral, M. Euan-Garcia, and L. Chavez-Nuñez, "Usefulness of community participation for the fine temporal monitoring of house infestation by nondomiciliated triatomines," Journal of Parasitology, vol. 95, no. 2, pp. 469-471, 2009.

[25] O. Cantillo-Barraza, E. Garcés, A. Gómez-Palacio et al., "Ecoepidemiological study of an endemic Chagas disease region in northern Colombia reveals the importance of Triatoma maculata (Hemiptera: Reduviidae), dogs and Didelphis marsupialis in Trypanosoma cruzi maintenance," Parasites and Vectors, vol. 8, no. 1, article no. 482, 2015.

[26] A. M. Mejía-Jaramillo, L. A. Agudelo-Uribe, J. C. Dib, S. Ortiz, A. Solari, and O. Triana-Chávez, "Genotyping of Trypanosoma cruzi in a hyper-endemic area of Colombia reveals an overlap among domestic and sylvatic cycles of Chagas disease," Parasites and Vectors, vol. 7, no. 1, article no. 108, 2014.

[27] F. Guhl, M. Restrepo, V. M. Angulo, C. M. F. Antunes, D. Campbell-Lendrum, and C. R. Davies, "Lessons from a national survey of Chagas disease transmission risk in Colombia," Trends in Parasitology, vol. 21, no. 6, pp. 259-262, 2005.

[28] J. Buendía, Guía de atención de la enfermedad de Chagas. Guías promoción la salud y prevención enfermedades en la salud pública, 2005: p. 1-48. 

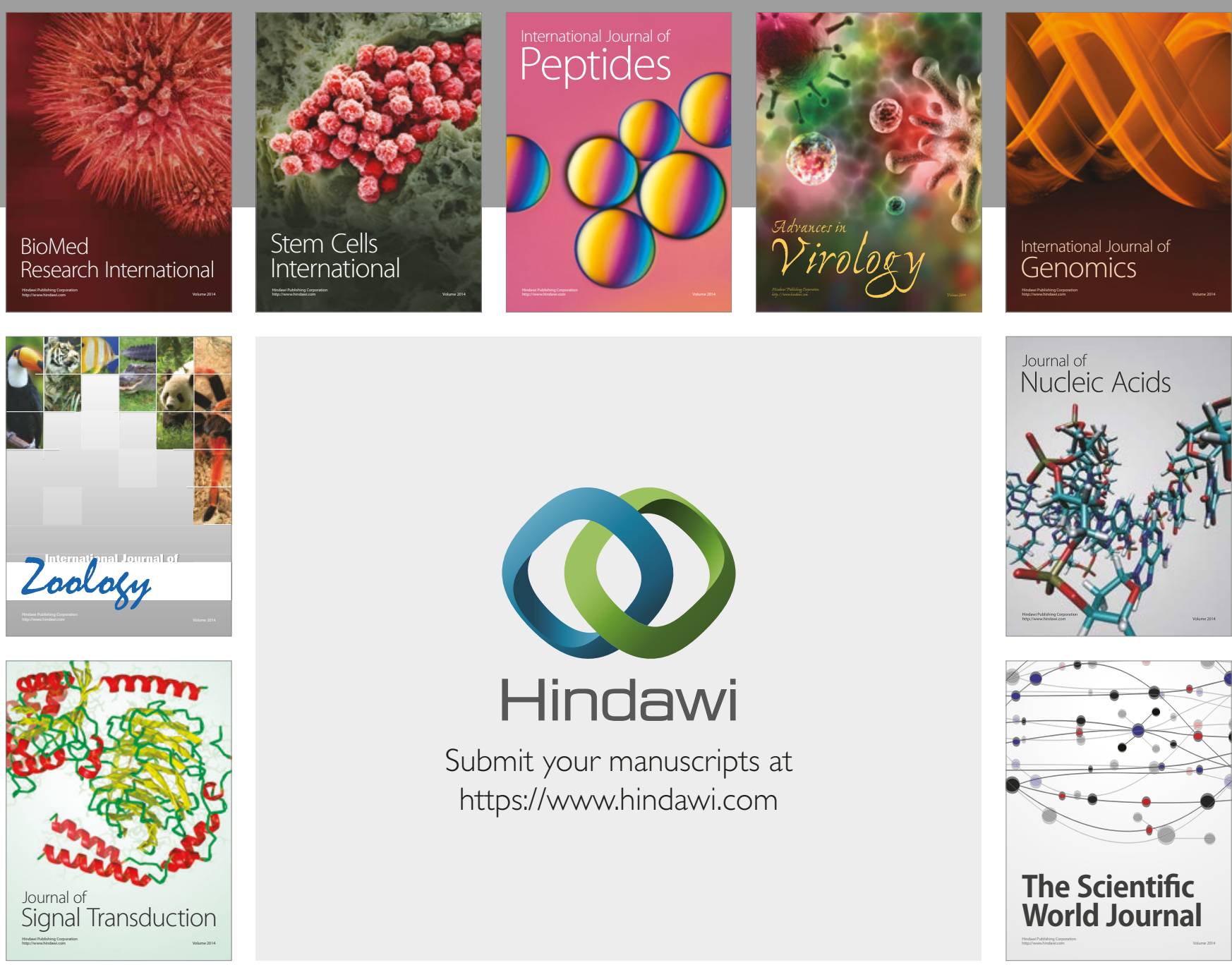

Submit your manuscripts at

https://www.hindawi.com
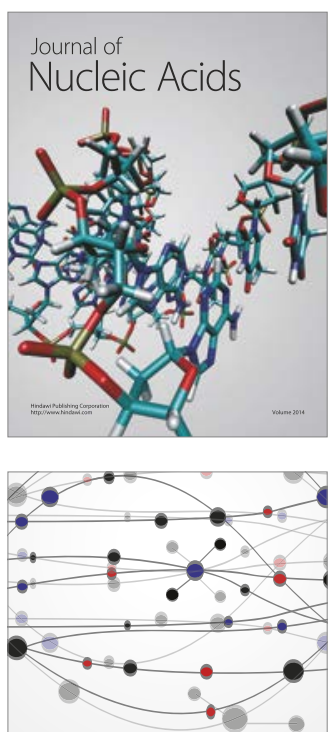

The Scientific World Journal

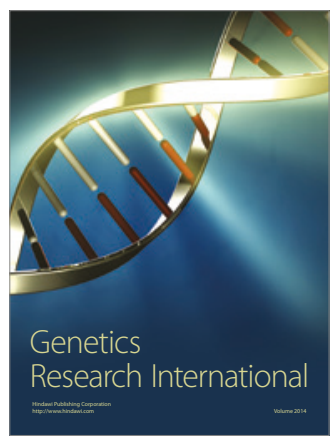

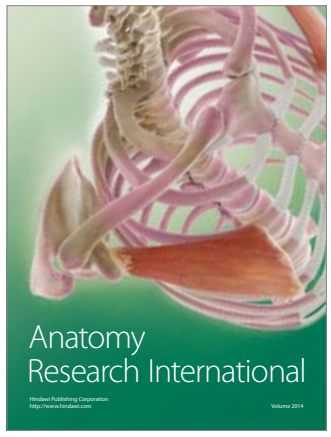

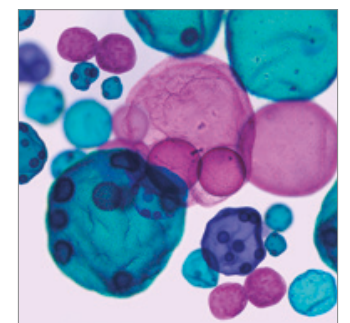

International Journal of Microbiology
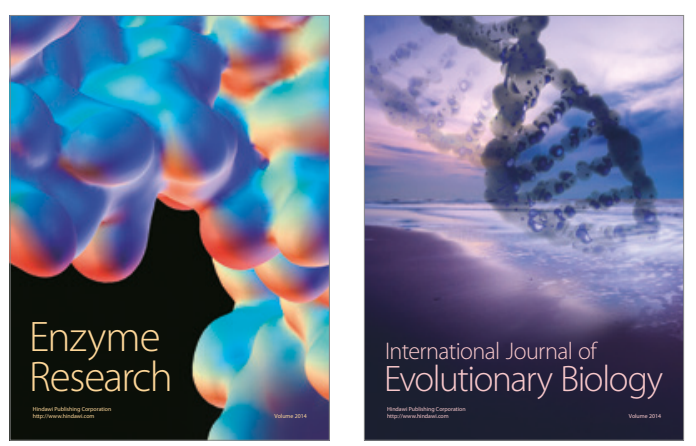
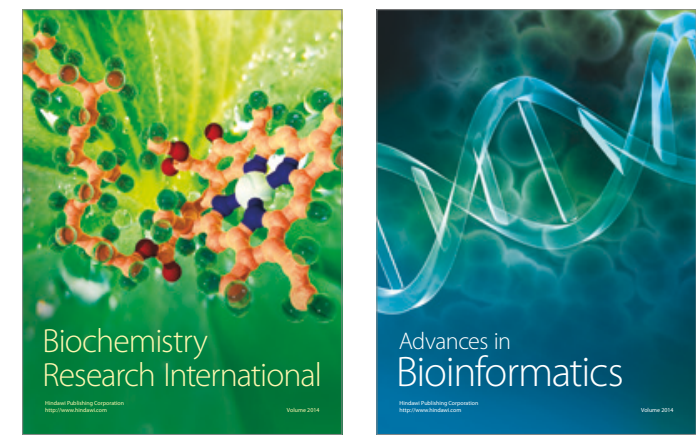

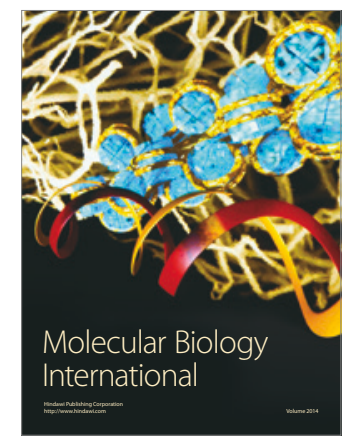

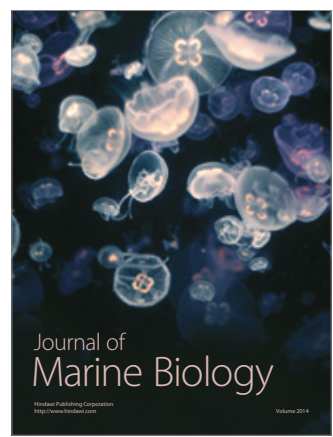

